numerous instances of co-existing epidote and clinozoisite assemblages. The crystallization periods of epidote and clinozoisite overlapped, yet the contacts between these minerals are boundaries between chemically and physically distinct crystals, with no evidence for replacement, or gradation of properties. Clinozoisite has nucleated on epidote, with the $b$-axes of the two minerals lying parallel. Optical properties and corresponding compositions of the co-existing crystals are given in Table 1.

\begin{tabular}{lcccl}
\multicolumn{5}{c}{ Table 1} \\
& $\delta$ & $P s(\%)$ & $N_{\beta}$ & $P s(\%)$ \\
Clinozoisite & $0.012-0.015$ & $11-13 *$ & $1 \cdot 717$ & $10 \cdot 4 \dagger$ \\
Epidote & $0 \cdot 035-0.042$ & $24 \cdot 4-28 \cdot 6$ & $1 \cdot 746$ & $25 \cdot 8$ \\
& $*$ Twelve pairs. & $\dagger$ One pair. & &
\end{tabular}

A gap therefore exists in the clinozoisite-epidote solid solution series between $C z_{76} P s_{24}$ and $C z_{87} P s_{13}$, under the $P-T-X$ conditions of epidote formation in the Borrowdale rocks, estimated ${ }^{7}$ at $P=1,000$ bars, $T=250^{\circ}-550^{\circ} \mathrm{C}$.

There is no evidence for co-existence of $\alpha$ - and $\beta$-zoisite, or of $\alpha$-zoisite and epidote. However, regrettably few petrographers determine which variety of zoisite is present in a rock, and there is a resultant lack of data relating to these minerals.

Zoisites are largely confined to rocks low in ferric iron and rich in calcium, and are commonest in high-grade rocks, such as gneisses, granulites, eclogites, and pegmatites. This may be attributed in part to the decrease in activity of ferric iron which is to be expected as tempera. ture increases; but it is likely that zoisite is also stable to higher temperatures than other epidote minerals. On this hypothesis, zoisite or thulite-epidote associations result from the disproportionation of a mineral of clinozoisite composition to iron poor zoisite and iron rich epidote, while the zoisite-hæmatite association of Cummington, Mass. ${ }^{8}$, may involve the breakdown of epidote to zoisite and hæmatite above the stability limit of epidote. From the few data available, it appears that the zoisite associated with epidote or clinozoisite is of the $B$ variety, as would be expected. The approximate ranges of the three 'stable' compositions are given in Table 2.

\begin{tabular}{lr}
\multicolumn{2}{c}{ Table 2 } \\
Common epidote & $P s(\%)$ \\
Clinozoisite & $30 \pm 10$ \\
$\beta$-Zoisite & $11 \pm 4$ \\
$(\alpha-$ Zoisite & $5 \pm 2$ \\
\hline
\end{tabular}

Ill-defined conditions exist under which intermediate compositions disproportion into epidote plus clinozoisite, or clinozoisite plus $\beta$-zoisite. Thulites so far examined have all been $\beta$-zoisites.

Since this work was done, experimental results have become available ${ }^{9}$ which show that $\beta$-zoisite-clinozoisite mixtures can be synthesized at pressures of $7 \cdot 2-9 \cdot 8$ kilo. bars, and temperatures of $655^{\circ}-700^{\circ} \mathrm{C}$, from starting materials of composition $C z_{95} P s_{5}$. These experimental data are in agreement with the deductions from field evidence.

This work was carried out in the Department of Geology, University of Nottingham, during tenure of a Department of Scientific and Industrial Research award.

Department of Geology,

R. G. J. Strens

University of Texas, Austin, 12.

${ }^{1}$ Winchell, A. N., and Winchell, H., Elements of Optical Mineralogy (Wiley, New York, 1951).

${ }^{2}$ Rogers, A. F., and Kerr, P. F., Optical Mineralogy (MeGraw-Hill, New York, 1959).

${ }^{3}$ Deer, W. A., Zussman, J., and Howie, R. A., Rock Forming Minerals, 1 (Iongmans, Green, Loridon, 1962)

4 Orlov, A., Mineral. Abstr., 4, 41 (1926).

- Foye, W. G., Amer. Min., 11, 210 (1926)

- Brothers, R. N., Amer. J. Sci., 252, 614 (1954),

" Strens, R. G. J., thesis, Univ. Nottingham (1962)

${ }^{8}$ Seki, Y., Amer. Min., 44, 720 (1959).

'Merrin, S., thesis, Pennsylvania State Univ. (1962).

\section{Fossil Hystrichospheres concentrated by Sieving Techniques}

THE hystrichospheres, a group of micro-organisms defined by shell constitution and morphology, with a size. range of $5-350 \mu$ and typically less than $120 \mu$, were first described fossil from translucent flakes of flint and chert in $1838^{1}$. Exactly a century later, it was demonstrated that assemblages could be concentrated from sediments by application of the chemical techniques developed for spore and pollen studies ${ }^{2}$. This has now become standard procedure, sediment samples being successively treated with hydrochloric acid, to dissolve carbonates, and hydrofluoric acid, to dissolve silicates; when necessary, the concentration of microfossils in the resultant residue may be further increased by heavy liquid separation or by mild oxidation, usually with Schulze's solution.

Recently one of us (S. H. E.) has succeeded in extracting hystrichospheres by utilizing a modification of the standard micropalæontological technique for concentration of calcareous microfossils. The specimen treated was of light grey, ironshot silty clay with abundant mica, from the Upper London Clay (Eocene) of the Whitehall Brick and Tile Co. Pit, Arborfield, Berks. (grid reference $S U$ 767654). After drying, the sample was soaked in water to bring about initial breakdown and washed through a sieve of British Standard 200 mesh (aperture between meshes $64 \mu$ ). The held residue was boiled with a suitable deflocculatory agent, sodium carbonate being used in this case. and re-sieved: this process should be repeated until all the clay fraction has been washed out and a clean residue obtained. After drying, the residue was examined under a binocular microscope at a magnification of $\times 60$. Hystrichospheres were found present in moderate numbers, sometimes isolate, more frequently included within mica flakes; no other microfossils were recognized. The hystrichospheres were transferred, on the moistened tip of a paintbrush, to a cavity slide for examination, any adherent mica being removed by gentle pressure of the brush tip.

The process was successfully repeated, a sample of London Clay of similar lithology from the Binfield Brick and Tile Co. Pit at Binfield, Berks. (grid reference $S U$ 848688 ) being treated. In each case, the hystrichospheres obtained were all relatively large forms attributable to species of the genus Hystrichosphaeridium. Since the London Clay is known to contain an extremely rich and varied hystrichosphere assemblage, it must be presumed that the majority of species present were too small in size to be retained by a sieve of this mesh and were washed away with the clay fraction.

Fossil hystrichospheres have not previously been extracted from sediments by physical methods of treatment; the microfossil groups most often studied (foraminifera and ostracods) are retained in sieves of 120 mesh, and finer concentrates are rarely examined. The sieving technique may prove of value for concentrating hystrichospheres from coarse and medium grained sandstones, when the bulk of the sediment would be retained in sieves of coarser mesh which the hystrichospheres themselves would pass through. However, even should a sieve of the finest mesh available (British Standard 350-aperture between meshes $44 \mu$ ) be used, retention of the whole hystrichosphere assemblage could not be guaranteed in view of the extremely meagre dimensions of the smallest forms. The use of this technique must thus inevitably involve some degree of implicit selection.

\section{Department of Geology,}

S. H. EAgar

University of Reading.

Department of Geology,

University of Nottingham.

W. A. S. SarJeant

${ }^{1}$ Ehrenberg, C. G., Abh. K. Akad. Wiss, Berlin, 1, 109J(1838).

2 Deflandre, G., Trav. Stat. Zool. Wimereux, 13, 147 (1938). 